\title{
Jurnal

\section{Pengaruh Sarana dan Prasarana Wisata Terhadap Kepuasan Wisatawan di Pulau Pasumpahan Padang}

\author{
Rahmad Ryanda ${ }^{1}$,Nidia Wulansari ${ }^{2}$ \\ ${ }^{1}$ Universitas Negeri Padang \\ 2 Universitas Negeri Padang \\ e-mail: Rahmadryanda180396@gmail.com, nidiawulansari@fpp.unp.ac.id
}

\begin{abstract}
Abstrak
Penelitian ini dilatar belakangi oleh kepuasan wisatawan yang berkunjung di pulau pasumpahan padang. Tujuan dari penelitian ini mendeskripsikan kepuasan wisatawan di pulau pasumpahan. Judul dari penelitian ini adalah Pengaruh sarana dan prasara wisata terhadap kepuasan wisatawan di pulau pasumpahan. Teknik yang dipakai komunikasi tidak langsung dengan cara menyebar kuosioner yang diberikan kepada wisatawan lalu di olah menggunakan program SPSS. Penelitian ini masuk kepada penelitian deskriptif kuantitatif dengan memakai metode asosiatif kausal. Dalam penelitian ini populasinya adalah wisatawan yang pernah berkunjung ke pulau Pasumpahan Padang, dengan sampel sebanyak 87 orang dengan teknik pengambilan sampel non probability sampling dengan penentuan sampel berdasarkan kriteria umur di atas 20 tahun. Data yang digunakan pada penelitian ini data primer dan data sekunder. Berdasarkan hasil penelitian yang telah dilakukan dengan penyebaran angket menggunakan metode skala likert. Data ini dianalisis menggunakan program SPSS versi 22.00. Hasil dari penelitian ini menyatakan sarana dan prasarana berada pada kategori kurang baik (56\%), kepuasan wisatawan berada pada kategori kurang puas $(77 \%)$ dan nilai R square 0,330 hasil uji hipotesis diperoleh nilai $F$ hitung 41,775 dengan sig $0,000 \leq 0,05$ dan diperoleh nilai t sebesar 6,463 dengan taraf sig 0,000 $<0,05$ mengartikan variabel $\mathrm{X}$ dapat mempengaruhi variabel $\mathrm{Y}$ secara signifikan. Maka variabel sarana dan prasarana X mempengaruhi variabel kepuasan Y. Diperoleh koefisien regresi sebesar 0,631 dengan signifikansi $0,000<0,05$ yang berarti setiap peningkatan 1 satuan sarana prasarana dapat meningkatkan 0,631 satuan kepuasan . Berdasarkan dari hasi penelitian, sarana dan prasarana mempengaruhi kepuasan wisatawan di pulau pasumpahan.
\end{abstract}

Kata kunci :Sarana prasarana, Kepuasan wisatawan. 


\section{PENDAHULUAN}

Indonesia dikenal sebagai Negara kepulauan, dibagi menjadi 34 provinsi yang memiliki potensi dan juga peluang besar di sektor pariwisata. Peluang tersebut didukung akibat dari kondisi alamiah seperti letak yang strategis, lapisan tanah yang subur dan panorama yang indah. Menurut [1] tentang kepariwisataan “ Objek Wisata yaitu segala sesuatu yang mempunyai keunikan, keindahan, dan nilai yang berupa keanekaragaman kekayaan alam, budaya serta hasil buatan manusia yang diolah menjadi sarana atau tujuan kunjungan wisatawan".

Kota Padang adalah ibukotanya provinsi Sumatera Barat. Kota Padang dikenal dengan wisata bahari karena berada di sepanjang pesisir pantai. Memiliki pantai yang panjang dan indah, tidak hanya pantai kota Padang juga memiliki destinasi wisata bahari yaitu pulau pasumpahan.

Terletak di perairan kecamatan Bungus Teluk Kabung Kota Padang Propinsi Sumatra Barat, pulau pasumpahan memiliki Jarak tempuh dari pusat Kota Padang sekitar \pm 2 jam menempuh jalur darat dan \pm 15 menit menempuh jalur laut dari sungai pisang. Untuk mencapai Pulau Pasumpahan dari kota Padang menuju kecamatan Bungus Teluk Kabung melewati simpang pisang lalu menuju desa sungai pisang. Transportasi penghubung dari Sungai Pisang menuju Pulau Pasumpahan menggunakan kapal wisata. Luas pulau pasumpahan \pm 5 hektar, hamparan pasir putih dan laut bening, spot foto yang menarik dan juga pemandangan yang indah dari atas bukit membuat pulau pasumpahan diminati wisatawan. Pulau pasumpahan ini sebagai objek wisata yang dapat menambah pemasukan bagi masyarakat desa sungai pisang.

Sarana yang tersedia di pulau pasumpahan yaitu: 5 kamar penginapan, Satu Warung makan, Tempat penampungan sampah, Musholla, Kamar mandi, Gazebo (tempat bersantai wisatawan). Ditunjang dengan prasarana seperti : Pelabuhan, Jalan, Transportasi Laut. Sesuai dengan teori ahli [2] "Sarana wisata merupakan kelengkapan daerah tujuan wisata yang dapat memenuhi kebutuhan wisatawan dalam menikmati perjalanan wisatanya.

Pengelolaan pulau pasumpahan bertujuan untuk memberikan kepuasan kepada wisatawan dan berharap untuk berkunjung kembali. Menurut [3]. Salah satu faktor timbulnya kepuasaan karena sarana \& prasarana yang memadai. Apabila sarana dan prasarana tidak memadai maka akan sebaliknya terjadi, tidak terciptanya kepuasan dan wisatawan tidak akan merekomendasikan pulau pasumpahan kepada orang lain dan menggunakan produk dan jasa itu kembali. Terdapat beberapa permasalahan yang terjadi di pulau pasumpahan padang, seperti Adanya wisatawan yang tidak bisa menikmati penginapan disaat hari libur karena penuh, Tidak terpenuhinya kebutuhan wisatawan karena kurangnya warung makanan di pulau pasumpahan, Tidak tercapainya keinginan wisatawan untuk menikmati pemandangankarena area pantai yang tidak bersih, Adanya wisatawan yang tidak puas karena kurang bersihnya air toilet dan kurangnya kamar mandi, Adanya keterbatasan tempat ibadah membuat wisatawan mengantri apabila masuk waktu sholat, Adanya kerbatasan jumlah gazebo di pulau pasumpahan membuat wisatawan tidak bias menggunakan sarana pelengkap wisata.

Dengan adanya keterbatasan sarana dan prasarana pulau pasumpahan, penulis mengharapkan pengelola pulau pasumpahan untuk lebih memperhatikan, memperbaiki serta menambah sarana dan prasarana guna menunjang tingkat kunjungan serta tingkat kepuasaan wisatawan yang berkunjung di pulau pasumpahan Padang. Apabila sarana dan prasarana di pulau pasumpahan tidak memadai maka tidak tercipta kepuasaan wisatawan. Begitupun sebaliknya apabila sarana dan prasarana di pulau pasumpahan memadai maka tercipata kepuasaan wisatawan.

\section{METODOLOGI}

Penelitian digolongkan pada penelitian deskriptif kuantitatif menggunakan metode asosiatif kausal. [4]. Penelitian terdiri dari dua variabel yakni variabel independent sarana prasarana wisata dan variabel dependen kepuasan. Populasi dalam penelitian ini ialah jumlah pengunjang yang datang ke pulau pasumpahan diambil dari jumlah pengunjung satu tahun terakhir (2019) sebanyak 7.600 pengunjung. 
Teknik pengambilan sampel ialah non probability sampling dengan Purposive sampling. Purposive sampling memakai teknik pemilihan sampel berdasarkan pertimbangan tertentu. Jadi total sampel yang diambil adalah 87 sampel. Jenis data memakai data primer dan data sekunder. Uji persyaratan yang dipakai pada penelitian ini yaitu uji normalitas dan uji homogenitas.

\section{HASIL PENELITIAN DAN PEMBAHASAN}

\section{a. Deskripsi Data Tentang Sarana dan Prasarana}

Data Sarana dan prasarana didapatkan melalui 23 pernyataan yang telah diuji validitas serta realibitasnya, dapat dilihat sebagai berikut:

\begin{tabular}{|c|c|c|c|}
\hline Kategori & Kelas Interval & Frekuensi & $\mathbf{( \% )}$ \\
\hline Sangat Baik & $\geq 91.95$ & - & - \\
\hline Baik & $76.65-<91.95$ & 38 & 44 \\
\hline Cukup Baik & $\mathbf{6 1 . 3 5}-<\mathbf{7 6 . 6 5}$ & $\mathbf{4 9}$ & $\mathbf{5 6}$ \\
\hline Buruk & $46.05-<61.35$ & - & - \\
\hline Sangat Buruk & $<46.05$ & 0 & - \\
\hline \multicolumn{2}{|r|}{ Total } & $\mathbf{8 7}$ & $\mathbf{1 0 0 \%}$ \\
\hline
\end{tabular}

b. Deskripsi Data Tentang KepuasanWisatawan (Y)

Berdasarkan data yang didapatkan hasil dari variabel kepuasan wisatawan di pulau pasumpahan padang sebagai berikut:

\begin{tabular}{|c|c|c|c|}
\hline Kategori & Kelas Interval & Frekuensi & $\mathbf{( \% )}$ \\
\hline Sangat Puas & $\geq 94.5$ & 0 & 0 \\
\hline Puas & $73.5-<94.5$ & 0 & 0 \\
\hline Kurang Puas & $\mathbf{5 2 . 5}-<\mathbf{7 3 . 5}$ & $\mathbf{6 7}$ & $\mathbf{7 7}$ \\
\hline Tidak Puas & $31.5-<52.5$ & 20 & 23 \\
\hline Sangat Tidak Puas & $<31.5$ & 0 & 0 \\
\hline \multicolumn{2}{|c|}{ Total } & $\mathbf{8 7}$ & $\mathbf{1 0 0 \%}$ \\
\hline
\end{tabular}

\section{Pengujian Hipotesis}

Didapat nilai F hitung 41.775 dengan sig. $0.000 \leq 0.05$ dan nilai t 2.491 pada taraf sig. $0.000<$ 0.05 . Maka model regresi dapat dipakai. Artinya variabel sarana dan prasarana berdampak signifikan pada kepuasan wisatawan.

Coefficients $^{a}$

\begin{tabular}{|c|c|c|c|c|c|c|}
\hline \multirow{2}{*}{\multicolumn{2}{|c|}{ Model }} & \multicolumn{2}{|c|}{ Unstandardized Coefficients } & Standardized & \multirow[t]{2}{*}{$\mathrm{T}$} & \multirow[t]{2}{*}{ Sig. } \\
\hline & & $B$ & Std. Error & Beta & & \\
\hline \multirow{2}{*}{1} & (Constant) & 21,272 & 7,663 & & 2,776 & ,007 \\
\hline & Sarana dan prasarana & ,631 & 098 &, 574 & 6,463 & 000 \\
\hline
\end{tabular}

a. Dependent Variable: Kepuasan

Sumber: Hasil Olah Data, SPSS 22.00 (2020)

Pada Tabel diatas didapatkan persamaan regresi sebagai berikut:

$$
\begin{gathered}
Y=a+b X \\
Y=21,272+0,631 X
\end{gathered}
$$


Berdasarkan rumus diatas didipatkan koefisien regresi sebesar 0,631 dan nilai sig. 0,000<0,05. Yang berarti setiap peningkatan sebesar 1 satuan Sarana dan Prasarana akan meningkatkan 0,631 satuan Kepuasaan Wisatawan . Selanjutnya untuk melihat seberapa besar pengaruh variabel Sarana dan Prasarana (X) terhadap Kepuasan Wisatawan (Y), maka dapat dilihatt pada tabel dibawah ini:

\begin{tabular}{|l|r|r|r|c|}
\hline Model & R & R Square & $\begin{array}{c}\text { Adjusted R } \\
\text { Square }\end{array}$ & $\begin{array}{c}\text { Std. Error of the } \\
\text { Estimate }\end{array}$ \\
\hline 1 &, $574^{\mathrm{a}}$ &, 330 &, 322 & 5,406 \\
\hline
\end{tabular}
a. Predictors: (Constant), Sarana dan prasarana
b. Dependent Variable: Kepuasan

Berdasarkan uraian pada tabel diatas, didapat nilai R Square sebesar 0,330 yang berarti pengaruh variabel X pada variabel Y ialah $33 \%$ dan $67 \%$ pada faktor lain. maka Ha diterima \& Ho ditolak.

\section{Pembahasan}

\section{Sarana dan Prasarana (X)}

Berdasarkan hasil pengolahan data dari 87 sampel, ditemukan bahwa variabel Sarana dan Prasarana secara keseluruahan menunjukan persentase 56\% pada rentan skor 61.35.- < 76.5 kategori kurang baik. Maka keadaan sarana dan prasarana wisata di pulau pasumpahan padang secara keseluruhan dikategorikan dalam keadaan kurang baik.

Pengelola pulau pasumpahan harus memperhatikan keadaan dan kelengkapan sarana dan prasarana yang ada untuk dipakai pengunjung agar wisatawan merasa puas dan akan kembali berkunjung ke pulau pasumpahan.

Sarana dan Prasarana (X) dilihat dari 4 indikator yaitu: a) Sarana PokokWisata dengan persentase $67 \%$ termasuk kategori baik, kurangnya warung makanan dan sering bertutup sehingga tidak adanya variasi menu makanan, kurangnya sarana pokok wisata dari perusahaan perjalanan wisata. b) indikator Sarana Pelengkap Wisata dengan persentase $70 \%$ termasuk kategori kurang baik, terbatasnya jumlah gazebo, kondisi musholla yang kecil, tidak adanya fasilitas olahraga, instalasi air bersih yang berbau dan keruh. c) indikator Sarana Penunjang Wisata dengan presentase $63 \%$ menunjukan kategori kurang baik, berdasarkan data yang diperoleh dari wisatawan meliputi: toko souvenir tidak buka dan kurangnya souvenir yang dijual tidak bervariasi. d) indikator prasarana dengan persentase $49 \%$ menunjukan kategori kurang baik. berdasarkan data yang diperoleh dari wisatawan meliputi: kurang bersihnya air yang ada dikamar mandi, tidak adanya pos kesehatan disekitar objek wisata dan tidak adanya pos keamanan.

Berdasarkan penjelasan di atas variabel sarana dan prasarana di pulau pasumpahan berada pada kategori cukup baik, dengan adanya penelitian ini diharapkan dapat menjadi gambaran bagi pengelola pulau pasumpahan untuk menambah serta mengelola sarana dan prasarana dengan lebih baik lagi. Hal ini dudukung oleh penelitian yang dilakukan oleh [5] terdapat pengaruh signifikan antara sarana dan prasarana terhadap kepuasan wisatawan dan juga didukung oleh penelitian [6] menunjukan pengaruh yang signifikan variabel sarana prasrana terhadap kepuasan. 


\section{Kepuasan (Y)}

Berdasarkan hasil pengolahan data dari 87 sampel, diketahui bahwa kepuasan di pulau pasumpahan secara keseluruhan menunjukan persentase sebesar $77 \%$ pada dg skor $52.5-<73.5$ dengan kategori kurang puas. Kepuasan wisatawan di pulau pasumpahan padang secara keseluruhan dikategorikan kurang puas. Hal ini sesuai dengan

Variabel Kepuasan (Y) dilihat dari 5 indikator yaitu: a) tercapainya harapan atau tujuan pengunjung berada pada kategori tidak puas dengan presentase $45 \%$, berdasarkan pernyataan data yang diperoleh dari pengunjung meliputi: terpenuhinya harapan pengunjung, terpenuhinya tujuan dan kesesuaian harga dengan harapan pengunjung. b) terpenuhinya kebutuhan pengunjung berada pada kategori kurang puas dengan persentase 51\%.c) tercapainya keinginanan pengunjung berada pada kategori tidak puas dengan persentase $30 \%$. d) keinginan untuk memakai produk dan jasa itu kembali denganp resentase $61 \%$ kategori kurang puas. e) keinginan merekomendasikan produk/jasa kepada orang lain berada pada kategori kurang puas dengan persentase $51 \%$, berdasarkan pernyataan data yang diperoleh dari wisatawan meliputi: menceritakan pengalaman kepada orang lain dan merekomendasikan pulau pasumpahan kepada orang lain.

Variabel Kepuasan di pulau pasumpahan beradapada kategori kurang puas, diharapkan kepada pihak pengelola pulau pasumpahan untuk memperhatikan dan meningkatkan faktor-faktor yang dapat mempengaruhi Kepuasan Wisatawan.

\section{Pengaruh Sarana dan Prasarana terhadap Kepuasan Wisatawan di Pulau Pasumpahan}

Hasil uji Regresi linear sederhana diperoleh F hitung 41.775 dengan sign $0,000<0,05$ maka artinya variabel sarana dan prasarana $(X)$ berpengaruh secara signifikan terhadap variabel kepuasan (Y), maka Ha diterima.

Kemudian koefisien determinasi diperoleh $\mathrm{R}$ square 0,330, artinya kontribusi variabel sarana dan prasarsna (X) terhadap variabel kepuasan (Y) adalah sebesar 33\% sedangan 67\% ditentukan oleh faktor lain. Sarana dan prasarana berpengaruh terhadap kepuasan sebesar 33\% karena indikator sarana dan prasarana adalah sarana pokok, sarana pelengkap, sarana penunjang dan prasarana wisata dapat mempengaruhi kepuasan wisatawan sehingga dapat disimpulkan semakin baik sarana dan prasarana yang tersedia maka dapat meningkatkan kepuasan wisatawan di pulau pasumpahan.

Dari hasil penelitian diperoleh hasil koefisien regresi sebesar 0,631 yang artinya setiap peningkatan 1 satuan sarana dan prasarana dapat meningkatkan 0,631 satuan kepuasan wisatawan, dapat diartikan bahwa baiknya sarana dan prasarana dapat meningkatkan kepuasan wisatawan.

\section{Kesimpulan}

\section{A. Kesimpulan}

1. Variabel X (sarana dan prasarana) dari indikator yang sudah ditentukan menunjukan secara keseluruhan dengan nilai persentase sebesar 56\% berada pada 61,35 $-<76,65$ termasuk kategori kurang baik.

2. Variabel y (kepuasan) dari indikator yang sudah ditentukan menunjukkan secara keseluruhan dengan nilai persentase sebesar 77\% berada pada 52,5 - <73,5 termasuk kategori kurang puas.

3. Terdapat pengaruh yg signifikan pada sarana dan prasarana wisata terhadap kepuasan wisatawan di pulau pasumpahan sebesar $33 \%$ sedangkan $67 \%$ dipengaruhi oleh faktor lainnya. 


\section{DAFTAR PUSTAKA}

[1] N. 10 T. 2009 Undang-Undang Republik Indonesia, "Undang-undang No 10 Tahun 2009 tentang Kepariwisataan," Bifurcations, 2009.

[2] Suwantoro, "Dasar-Dasar Pariwisata," J. Chem. Inf. Model., 2002.

[3] R. Somad and D. J. Priansa, Manajemen Supervisi dan Kepemimpinan Kepala Sekolah. 2014.

[4] Sugiyono, "Metode Penelitian," Metod. Penelit., 2015.

[5] W. Andesta, "PENGARUH FASILITAS TERHADAP KEPUASAN TAMU MENGINAP DI HANNAH HOTEL SYARIAH PAINAN,” J. Pendidik. DAN Kel., 2019, doi: 10.24036/jpk/vol11-iss1/582.

[6] A. Kiswantoro and D. R. Susanto, "Pengaruh Sarana Dan Prasarana Pendukung Wisata Terhadap Kepuasan Wisatawan Di Umbul Ponggok, Klaten," Khasanah Ilmu - J. Pariwisata Dan Budaya, 2019, doi: 10.31294/khi.v10i2.6373. 